\title{
Phenomenon of Nasza Klasa (Our Class) Polish Social Network Site
}

\author{
Andrzej Małachowski \\ University of Economics, Wroclaw, Poland
}

\author{
andrzej.malachowski@ue.wroc.pl
}

\begin{abstract}
The phenomenal success and popularity of a new Polish social networking portal Nasza-klasa.pl (Our Class) is discussed. Essentials information on the portal, its functions and usability features are presented, together with an overview of technological platform employed. Statistical data is provided where appropriate to illustrate the phenomenon under study. The study attempts to provide a model method for success in the e-market and inspiration for prospective entrepreneurs in the world of virtual services.
\end{abstract}

Ke ywords: social network site, virtual community, model of e-bus iness

\section{Introduction}

The design, implementation and success of the social networking portal Nasza-klasa (Our Class) is a model example of the 'rags to riches' ideal of an enterprise construed with no financial funding and no institutional support (ne ither from ASP/ISP corporations nor from central/local administration). Today, Nasza-klasa.pl ranks among top five Polish social community networking portals, not far behind Google.pl, Onet.pl and Wirtualna Polska (.pl), and followed by Allegro.pl - the biggest Polish Internet auction service. Nasza-klasa is visited monthly by more than $50 \%$ of Polish Internet users. There are several hundred of similar social networking services on global emarket. What are the reasons for this particular portal to reach such spectacular success on Polish e-market? First, it corresponds with the elementary need to communicate, a basic treat of human civilization (Barney, 2008; Castells, 2007; Mendes et al., 2004). Secondly, its authors were able to identify a very attractive business niche - after all, each individual has a certain history of social contacts in schooling communities (on elementary, secondary or university level). Thirdly, the portal under study offers a range of functionality and usability features that are well adapted to the needs and expectations of its users. Fourthly, the portal has strong foundation in the form of a constantly improved technological platform that offers stability, infallibility and excellent operational effic iency. Fifthly, Nasza-klasa has recorded a phenomenal, snowballed increase of unique registered users and visits, reaching the status of one of the most popular Polish sites

Material published as part of this publication, either on-line or in print, is copy righted by the Informing Science Institute. Permission to make digital or paper copy of part or all of these works for personal or classroom use is granted without fee provided that the copies are not made or distributed for profit or commercial advantage AND that copies 1) bear this notice in full and 2) give the full citation on the first page. It is permissible to abstract these works so long as cred it is given. To copy in all other cases or to republish or to post on a server or to redistribute to lists requires specific permission and payment of a fee. Contact Publisher@InformingScience.org to request redistribution permission. within seven months. Incidentally, there is also a diversity of social graphs evolving on the site, illustrating various relations and ties between individual members on Nasza-klasa community. In general, those social graphs are carefully studied and analyzed by social scientists in such varied subjects as ethnology, sociology, psychology, economics, political studies, law, criminology (Boyd \& Ellison, 2007). This particular aspect 
of Nasza-klasa operation is also emphasized in this study.

\section{Basic Information about Nasza-klasa}

In mid 2006, four students of Wroclaw University of Technology and University of Economics (Poland) devised and implemented a simple social networking portal addressed to members of present and past schooling and university communities. The prototype website came online in November, 2006 ("Nasza-klasa.pl,tour3", 2008d). The following three quarters saw a substantial increase in the number of registered users, mainly from Wrocław and the Lower Silesia region. Site popularity was noticed by global capital investment funds. As a result, the portal obtained a significant financing support. A limited liability company was established under the name of Nasza Klasa. By the end of 2007, following the renown, press reports and word-of-mouth communication, the number of registered users doubled every month ("Sukces naszej klasy", 2008). Consequently, at the turn of 2008, the snowball effect culminated in technological clogs that seriously affected website utility. To address this problem, company owners decided to incorporate another investor from the IT sector. The financial surge allowed to improve the service infrastructure; by the third quarter of 2008, technological and functional aspects of site operation and efficiency were stabilized ("Nasza-klasa.pl", 2008b). By the end of 2008, the company extended its organizational structure, updated their business model and provided new products and functionality features on the site. Table 1 presents results of a study (conducted in June, 2008) of most popular Polish websites, in terms of numbers of users, visits per month (as \% of total Internet users), number of vis its and average time spent viewing the site.

Table 1: Top Polish we bsites by number of use rs, visits and time spent vie wing a site

\begin{tabular}{|l|l|c|c|c|l|}
\hline No. & Portal & $\begin{array}{c}\text { Users } \\
\text { (million) }\end{array}$ & $\begin{array}{c}\text { \% of all } \\
\text { Internet } \\
\text { users per } \\
\text { month }\end{array}$ & $\begin{array}{c}\text { Visits of } \\
\text { users } \\
\text { (bln) }\end{array}$ & $\begin{array}{c}\text { Average time } \\
\text { of visit for one } \\
\text { user (h:m:s) }\end{array}$ \\
\hline 1 & Google & 12.7 & $85.4 \%$ & 3.1 & $05: 16: 22$ \\
\hline 2 & Onet.pl & 9.7 & $64.9 \%$ & 3.6 & $06: 10: 04$ \\
\hline 3 & Wirtualna Polska & 8.2 & $55.1 \%$ & 2.0 & $04: 43: 33$ \\
\hline 4 & nasza-klasa.pl & 7.6 & $51.1 \%$ & 8.2 & $09: 13: 31$ \\
\hline 5 & Allegro.pl & 7.6 & $50.6 \%$ & 3.8 & $03: 52: 44$ \\
\hline 6 & Interia.pl & 7.4 & $49.6 \%$ & 1.1 & $03: 12: 15$ \\
\hline 7 & 02.pl & 7.0 & $47.2 \%$ & 1.0 & $03: 36: 39$ \\
\hline 8 & Gazeta.pl & 7.0 & $47.1 \%$ & 0.7 & $01: 47: 11$ \\
\hline
\end{tabular}

Source: ("Panel badania Gemius", 2008)

As shown above, nasza-klasa.pl ranked fourth among the websites under study in terms of monthly percentage of users and total number of registered users (7.6 million), and dominated the list in terms of vis its $(8.2 \mathrm{bln})$ and average monthly time spent online per user ( $9 \mathrm{~h}, 13 \mathrm{~min}, 31$ sec). Currently (November, 2008), the number of users is estimated about 11 million.

The number of Nasza-klasa visitors almost equals the sum of users visiting all three websites that ranked higher. This fact alone confirms the vast popularity and intense traffic on the site. Moreover, users spend decidedly more time here compared to the other sites under study, which proves that functions and usability features offered by Nasza-klasa attract their attention. Obviously, these characteristics make the portal equally attractive from the viewpoint of e-marketing and product promotion. 
The most important measures of website popularity evaluation are the number of unique users and the number of visits. The dynamic increase of unique user numbers in the period between July 2007 and August 2008 is shown in Figure 1.

In 2007 alone, the number of unique users doubled every month to a stable, extremely high value of about 40 million. Total number of Internet users in Poland is estimated about 17 million.

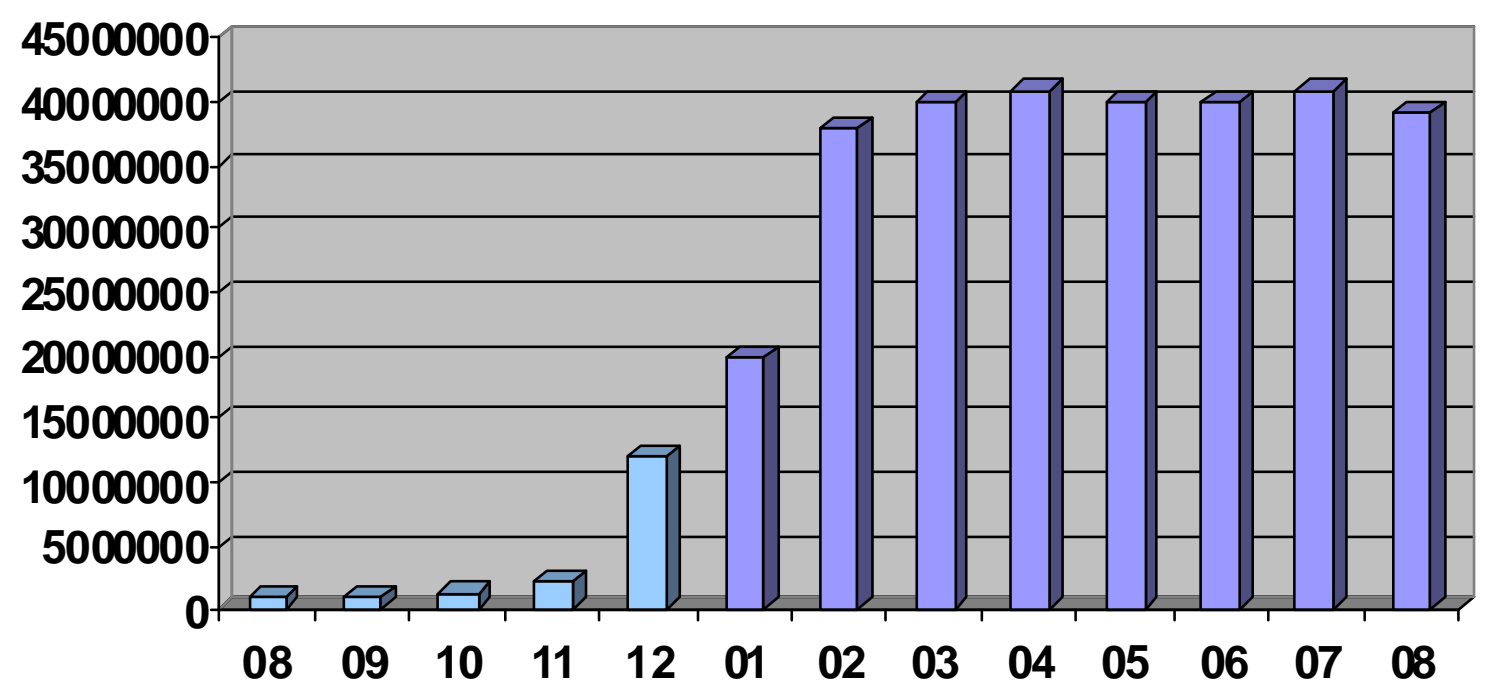

Figure 1: Number of unique use rs of Nasza-klasa.pl by month (Aug/2007- Aug/2008) Source: ("Badanie Megapanel PBI/Gemius", 2008)

The snowball effect, observed in the number of visits for the period of September 2007 - July 2008 is shown in Figure 2.

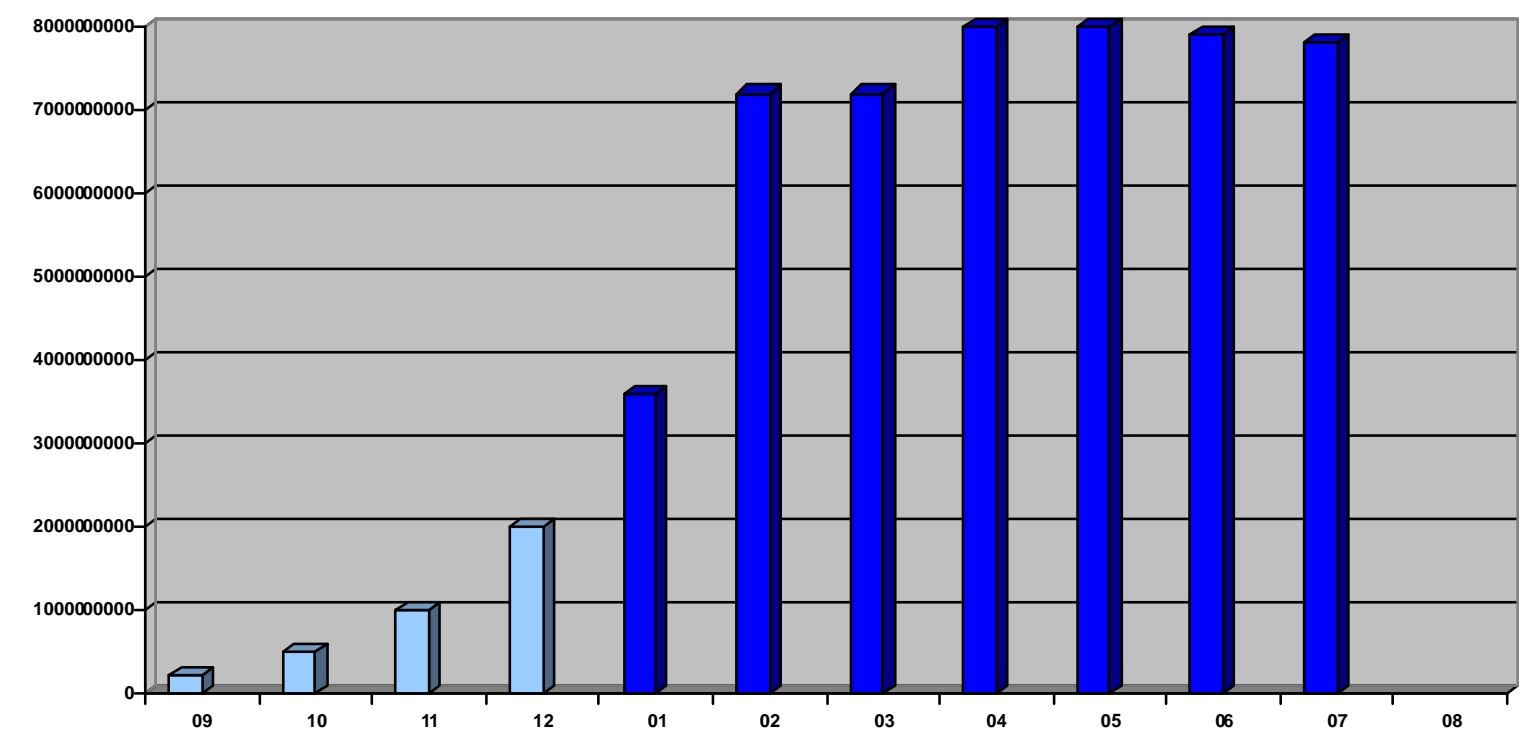

Figure 2: Number of nasza-klas a.pl visits per month Source: (“Badanie Megapanel PBI/Ge mius”, 2008) 
In the period between Jul-Dec 2007 alone, the value increased fivefold, with further threefold increase between Jan-Aug 2008. It is also evident that, from April 2008 onwards, the number of visits stabilized at a very high level of about 8.5 billion per month. Thus, the portal is intensively used, both on monthly and daily basis.

The most recent data (Google Trends, 2008) shows significant changes in Nasza-klasa portal use (Figures 3 and 4).

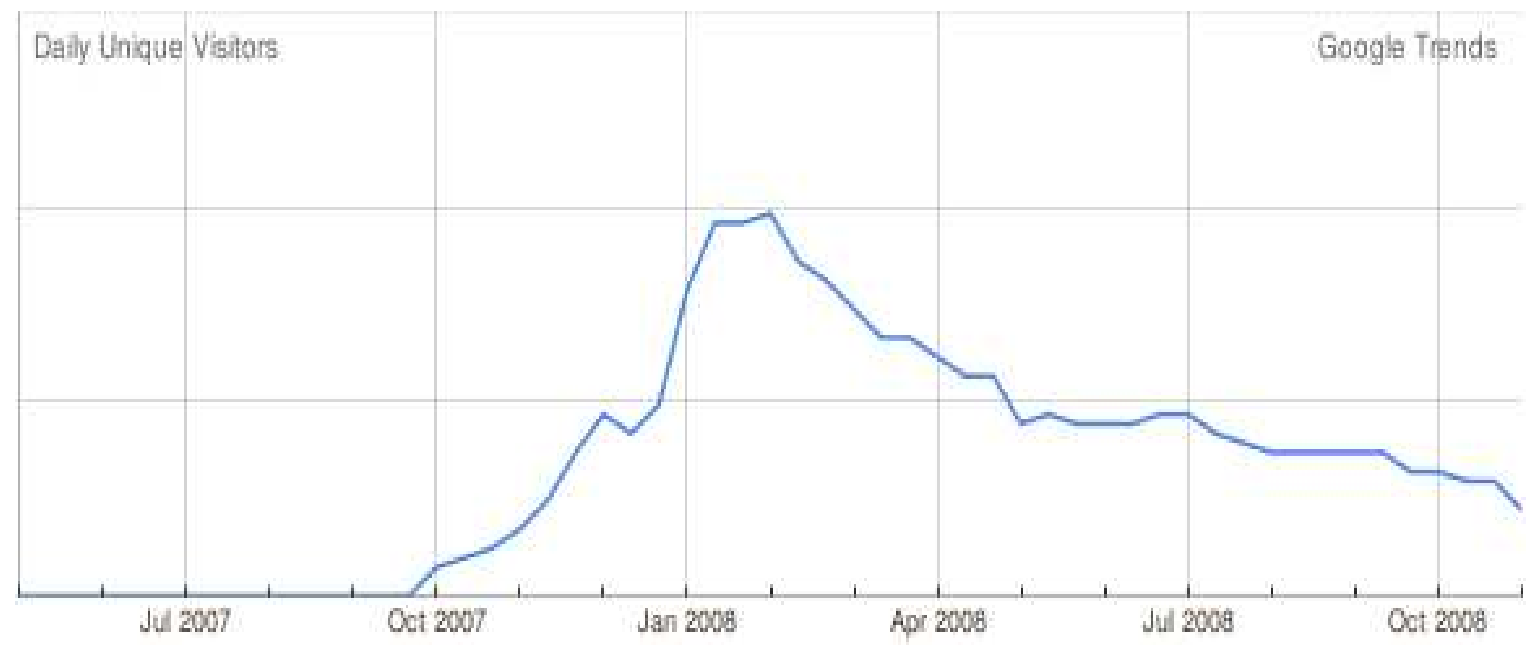

Figure 3: Downward trend in daily visits of Nasza-klas a unique use rs in the year 2008 Source: ("Google Trends", 2008)

Figure 3 shows a distinct drop in the number of daily unique vis itors over the year 2008 to the level registered in Nov-Dec 2007 (cf. Figure 1). The decrease may be attributed to the loss of initial valor of nove lty and attractiveness of the portal. Does Nasza-klasa face the Classmates.com syndrome of spectacular failure?

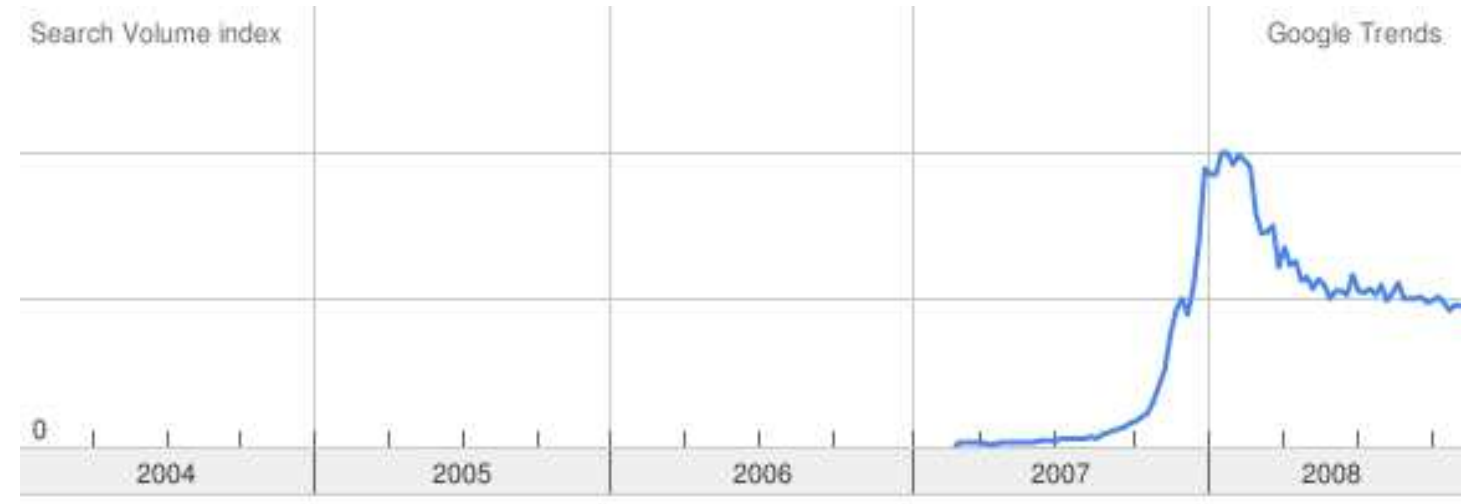

No data avalable

Figure 4: Stabilization of Nasza-klas a portal visits in the $2^{\text {nd }}$ and $3^{\text {rd }}$ quarter of 2008 Source: (“Google Trends", 2008)

If that is the case, then the portal management team will be forced to bring certain modifications into their existing business model (cf. Afuah \&Tucci, 2003).

The relative stabilization in the number of visits on the site (Figure 4) seems to confirm the increased activity of the declining user base (Figure 3). Nonetheless, the number of visits has also 
dropped significantly (by ca. 50\%), down to the level registered in Nov-Dec 2007 (cf. Figure 2). The noteworthy observation is that the most loyal users display increased activity - this group should be the targeted in the new business model. The portal should be extended with new functionality. It may be worth examining whether the management of Nasza-klasa is fully aware of the ramifications of this tendency and ready to face the situation.

\section{Functional Description of Nasza-klasa}

The portal was designed as a meeting place for members of existing and past classmate communities, a place to exchange information and communicate. The initial address database contained more than 60 thousand Polish schools ("Nasza-klasa.pl", 2008a). The dynamic increase of user base was a consequence of the website's basic, free-of-charge functionality ("Nasza-klasa.pl", 2008b, 2008c, 2008d), such as:

- easy creation, query and sign-up of school communities, based on territorial reach, school level, graduation date,

- user profile creation,

- personalized list of acquaintances,

- $\quad$ search and browse of other users' profiles, with options for browsing and commenting photo-gallery entries, browsing and commenting user profiles, importing contacts from popular instant messaging (IM) applications: Gadu-Gadu and Skype,

- free photo gallery,

- numerous open-access discussion forums,

- built-in website messaging system (POST).

Querying the list of registered users in search of close and distant acquaintances (classmates) is the most basic functionality feature of Nasza-klasa, followed by other features, such as messaging, gallery management and forum discussions.

With time, the website was extended to offer new functionality features, such as:

- list of active (online) acquaintances,

- labeling and identifying persons presented on group photos,

- labeling and differentiating between real-life and fictitious user profiles,

- auctions.

The extended business model included also a number of optional, chargeable features, such as:

- identification of users visiting 'my profile',

- extending the limit of photo upload,

- sending virtual presents,

- cross-linking photo upload and download with cellular phones.

The range and recognition of bas ic functionality features used by persons registered in Naszaklasa is shown in Figure 5. The most popular features include browsing friends' galleries, identifying users that recently browsed 'my profile', sending and receiving messages. Creation of forums, class/group profiles and fictitious user profiles were reported to be the least popular. 


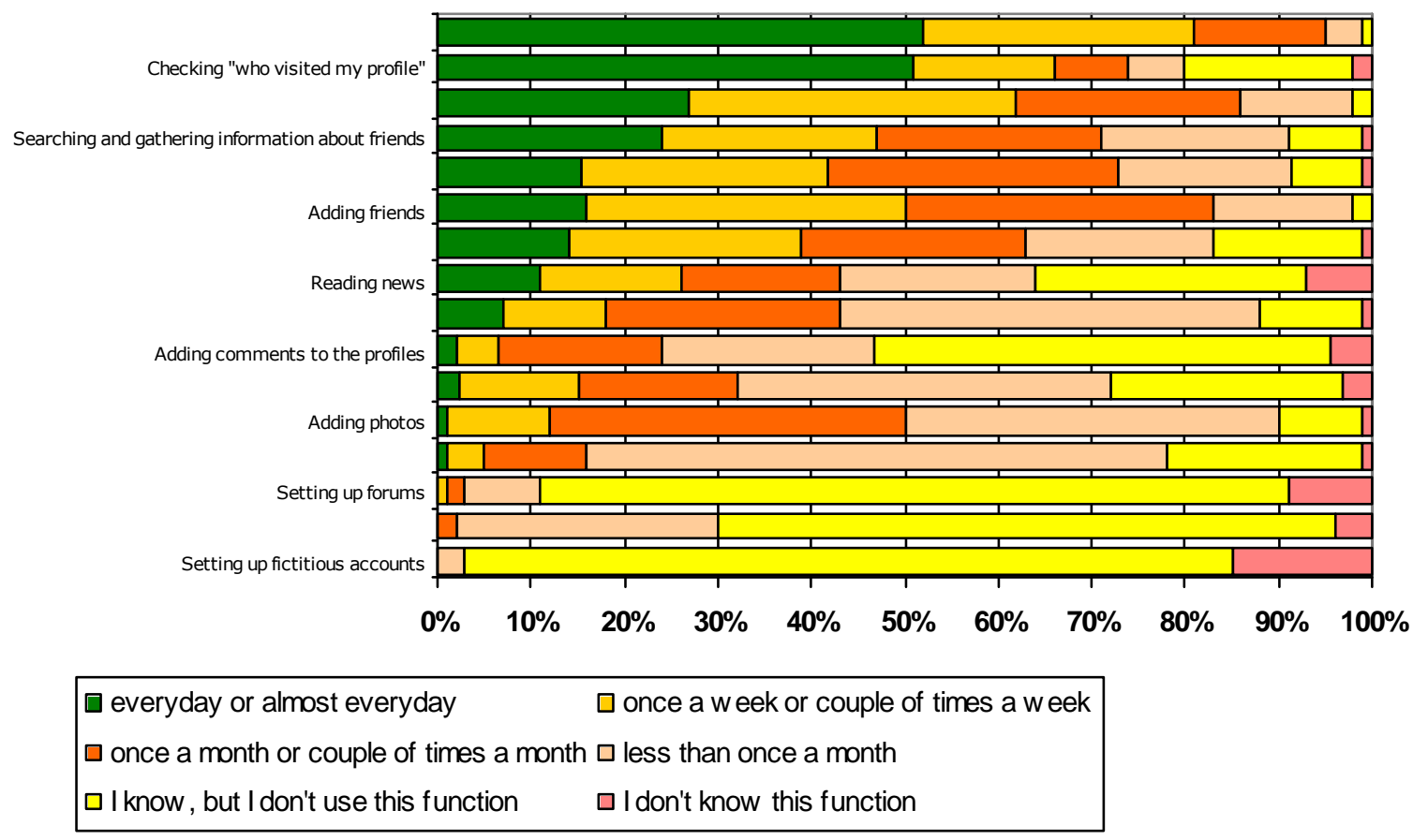

Figure 5: The use of basic functionality features of Nasza-klas a.pl Source: ("Raport z badania ilosc iowego", 2008)

\section{Website Technological Platform}

In terms of technology, the initial Nasza-klasa.pl service system is divided in two relatively autonomous subsystems: database application and photo management/storage service. Due to the snowball increase of user base, both systems faced acute scalability problems.

The initial system was designed using MySql database standard (Pernal, 2008). MySql systems offer efficient I/O operation service: MySql database is stored on 80 FC (Fiber Channel) disks with multipathing over SAN network and 3PAR matrix. Additionally, the efficiency of application is improved through horizontal and vertical distribution of problem tables between servers: horizontally - with single table distributed across servers; vertically - with tables duplicated across servers. The core of service application is designed using PHP.

The system is based on several independent PHP server clusters (Pernal, 2008):

- static.nasza-klasa.pl, to service static content (css, js files),

- $\quad$ upload.nasza-klasa.pl, to store photo files uploaded by users,

- ph.nasza-klasa.pl, to store user-sent messages (POST),

- $\quad$ nasza-klasa.pl, to service data upload requests from users.

The latter requires considerable processing power. As such, it consists of 104 servers, mostly 8core type, with up to 160 processes each. The application set of Nasza-klasa is based on HP Blade servers, offering ease of management, stability and effic iency. The hardware structure of naszaklasa.pl system consists of 9 sets of $16 \mathrm{HP}$ Blade servers each, supported by 160 traditional, fast servers (those will be gradually replaced by Blade-type servers) (Pernal, 2008). 


\section{Conclusions}

Undoubtedly, the social networking service of Nasza-klasa has proved enormously successful on the virtual market of Polish Internet. Nasza-klasa is still one of the most popular Polish websites, attracting more than 50\% of Polish Internet users. Interestingly, as shown in this author's research, the functionality features offered by Nasza-klasa have inspired a lot of new users - middle aged and older, people from small towns and rural areas - previously indifferent to the possibilities offered by the Internet. Moreover, ca. $10 \%$ of the portal traffic (i.e., ca. 1 million users) originates from abroad. Nasza-klasa has come to be one of the most widely recognized Polish ebrands. Marketing potential and new chargeable functional content is proof that the portal gradually evolves to incorporate a new business model and attempts to secure a stable basis for further development, especially in the field of e-business. These new trends will be carefully studied in the future.

\section{References}

Afuah A., \&Tucci, C. (2003). Biznes internetowy, strategie i modele. Wyd. Oficyna Ekonomic zna, Krakow.

Badanie Megapanel PBI/Gemius. (2008), Retrieved September 18, 2008 fro m $\underline{\text { http://panel.pbi.org.pl/wyniki }}$

Barney, D. (2008). The Network Society. wyd. SIC, Warszawa.

Boyd, D., \& Ellison, N. (2007). Social network sites: Definition, history, and scholarship. Journal of Computer-Mediated Communication, 13(1), article 11. Retrieved October 24, 2008 from http://jcmc.indiana.edu/voll3/issue1/boyd.ellison

Castells, M. (2007). The rise of the network society. PWN, Warszawa.

Google trends for websites. (2008). Retrieved November 14, 2008 fro $\mathrm{m}$ http://www.google.com/trends

Malachowski, A. (2005). Virtual customer environment (in Polish), AE Wroclaw.

Mendes, M., Sou mi, R., \& Passos, C. (2004). Dig ital commun ities in a networked society. New York: Kluwer.

Nasza-klasa.pl,about. (2008a), Retrieved November 17, 2008 from http://nasza-klasa.pl/about

Nasza-klasa.pl,tour1. (2008b). Retrieved November 17, 2008 from http://nasza-klasa.pl/tour/1

Nasza-klasa.pl,tour2. (2008c). Retrieved November 17, 2008 from http://nasza-klasa.pl/tour/2

Nasza-klasa.pl,tour3. (2008d). Retrieved November 17, 2008 from http://nasza-klasa.pl/tour/3

Panel badania Ge mius Traffic. (2008). Retrieved September 19, 2008 from www.ge mius.p1/Engine/Main.php

Pernal, A. (2008). Social network sites based on example of Nasza-klasa (in Polish). Masters thesis, University of Econo mics, Wroclaw, Poland.

Raport z badania ilosciowego lipiec-sierpien 2008 Nasza-klasa. (2008), IMAS International, Wrocław.

Sukces Naszej Klasy. (2008). Retrieved November 19, 2008 from http://miasta.gazeta.pl/wroclaw 


\section{Biography}

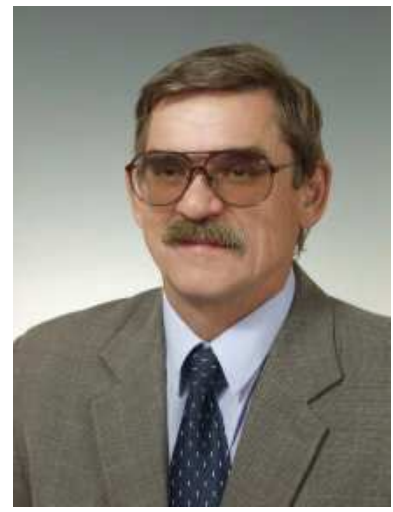

Andrzej Malachowski (*1944), Ph D. (1977) in operation research, university professor (1994). Wroclaw University of Economics (Poland), Management and Informatics Faculty, Institute of Business Informatics. Head of Business Communication Department. Main scientific interests: business informatics, e-business, business communication. On these fields author and co-author more than 20 books and 80 papers. 12 doctors degree had conferred. 